\title{
Nutritional Characteristics of Black Rockfish (Sebastes schlegeli) Fed a Diet of Fish Skin
}

\author{
Sung-Ju Rha ${ }^{1}$, Jae-Kwon Cho², Seon-Jae Kim³ ${ }^{3}$ Wook-Min Park ${ }^{3}$, Tai-Sun Shin ${ }^{4}$ and Jae-Ho Hwang ${ }^{1 *}$ \\ ${ }^{1}$ College of Fisheries and Ocean Sciences, Chonnam National University, Yeosu 550-749, Korea \\ ${ }^{2}$ Southwest Sea Fisheries Research Institute, National Fisheries Research and Development Institute (NFRDI), Yosu 556-823, Korea \\ ${ }^{3}$ Department of Marine Bio Food Science, College of Fisheries and Ocean Science, Chonnam National University, Yosu 550-749, Korea \\ ${ }^{4}$ Division of Food Nutrition Science, Chonnam National University, Gwangju 500-757, Korea
}

\begin{abstract}
This study investigated the effects of diets substituted with different levels $(0,5,10$, and $20 \%)$ of flounder skin meal (FSM) on the nutritional composition of black rockfish Sebastes schlegeli. Fish $(10.05 \pm 0.44 \mathrm{~g})$ were fed to apparent satiation twice daily for 8 weeks. Adding FSM decreased crude lipid levels and increased crude protein and ash. The abundant fatty acids in the FSM-added group were C16:0, C18:1-cis (n9), and C22:6n-3. The major amino acids in the samples were glutamic acid, aspartic acid, glycine, leucine, alanine, lysine, and arginine. The abundant free amino acids in the FSM-added group were taurine, glutamic acid, alanine, leucine, and arginine. Six free sugars were found in all groups. Glucose was predominant, followed by mannose, rhamnose, fucose, fructose, and ribose. Among the three organic acids in the whole body of black rockfish, lactic acid was predominant, followed by citric acid and oxalic acid. Total organic acid content in the control was significantly higher than those of FSM substitution groups.
\end{abstract}

Keywords: Fish skin; Black rockfish; Organic acid; Free sugar; Fatty acid; Amino acid

\section{Introduction}

Numerous studies have been investigated vegetable and animal proteins that could replace fishmeal in fish feed. In particular, there have been many studies on the use of vegetable protein sources such as soybean meal [1-4], cottonseed meal, and rapeseed meal [5,6], which have a relatively stable supply compared to fishmeal, to replace fishmeal as a source of protein. However, plant resources are constantly in competition with livestock and human consumption, and the recent development of plant extract fuels such as bioethanol will eventually lead to an increase in the price of the plant resources usable as protein resources [7]. The by-products of the processing of terrestrial livestock such as cows, chickens, and pigs could be used as animal protein sources, since they have a relatively high protein content and qualitatively similar amino acid composition to fishmeal, and are inexpensive and stably supplied. Various studies have been conducted on their use as protein sources to replace fishmeal in fish feed [8-13]. However, the rise of safety issues due to serious infectious diseases like mad cow disease, swine fever, and avian influenza has gradually restricted the use of livestock by-products lately. Thus, as there are economic and safety issues with using terrestrial protein sources to replace fishmeal, securing economic and safe protein sources from marine products rather than terrestrial products is necessary. Many researchers have investigated by-products obtained from processing marine animal as potential protein sources, including shrimp by-products [14], tuna muscle by-products [15], shrimp and fish by-products [16], squid liver meal mixing soybean meal with by-products of squid processing [11], fish bone and crab by-products [17-19], and fish by-products [20]. Of the fishery by-products, even though fish skins obtained from the consumption of raw fish are a good protein source because of high collagen content, by-products such as bones and internal organs are only partially used and mostly discarded.

Therefore, this study was conducted to investigate improvement of quality and physiological function on cultured black rockfish fed diets substituted with different levels $(0,5,10$, and $20 \%)$ of flounder skin meal (FSM).

\section{Materials and Methods}

The skin of Paralichthys olivaceus, which has the highest farming yield and raw fish consumption in Korea, is easy to secure in large quantities due to its low use, thickness, and high collagen content, and was obtained from nearby fish markets. The fish skin was washed with fresh water and was subjected to hot air drying $\left(50-60^{\circ} \mathrm{C}\right)$ followed by grinding via a high speed grinder (ZM-1000, Retsch Co., Japan) to prepare flounder skin meal (FSM).

After acclimation for 2 months in a square stock tank (running water system, $6.0 \mathrm{~m} \times 6.0 \mathrm{~m} \times 1.2 \mathrm{~m}$ ) at the Fisheries Science Institute, Chonnam National University, Korea., 45 juvenile fish (mean body weight, $10.05 \pm 0.44 \mathrm{~g}$ ) were randomly selected from the stock tank and transferred to separate $300-\mathrm{L}$ rectangular tanks (running water system, $1.0 \mathrm{~m} \times 0.8 \mathrm{~m} \times 0.8 \mathrm{~m}$ ). The flow rate of filtered seawater in each tank was adjusted to $5 \mathrm{~L} / \mathrm{min}$. Mean water temperature, salinity, and dissolved oxygen were $20.2 \pm 2.3^{\circ} \mathrm{C}, 32.0 \pm 1.2 \mathrm{psu}$, and $6.3 \pm 0.4 \mathrm{mg} / \mathrm{L}$, respectively, and were measured using a YSI-85 (YSI, Ohio, USA) probe. The rearing trial was conducted in triplicate for each tested diet. The fish were fed twice a day (at $0800 \mathrm{~h}$ and $1600 \mathrm{~h}$ ), until apparent satiation, for 8 weeks. The amount of feed given to each tank was recorded daily to calculate feeding efficiency.

Ingredients and proximate compositions of the experimental diets in response to FSM substitution and the results of vitamin $\mathrm{C}$ analyses are shown in Table 1. Proximate analyses were carried out to evaluate

*Corresponding author: Jae-Ho Hwang, College of Fisheries and Ocean Sciences, Chonnam National University, Yeosu 550-749, Korea, Tel: +82-70-7612 0537; Fax: +82-61-724-0538; E-mail: hwangjh73@yahoo.co.kr

Received April 28, 2014; Accepted June 19, 2014; Published June 29, 2014

Citation: Rha SJ, Cho JK, Kim SJ, Park WM, Shin TS, et al. (2014) Nutritional Characteristics of Black Rockfish (Sebastes schlegeli) Fed a Diet of Fish Skin. J Aquac Res Development 5: 239 doi:10.4172/2155-9546.1000239

Copyright: ( 2014 Rha SJ, et al. This is an open-access article distributed under the terms of the Creative Commons Attribution License, which permits unrestricted use, distribution, and reproduction in any medium, provided the original author and source are credited. 
Citation: Rha SJ, Cho JK, Kim SJ, Park WM, Shin TS, et al. (2014) Nutritional Characteristics of Black Rockfish (Sebastes schlegeli) Fed a Diet of Fish Skin. J Aquac Res Development 5: 239 doi:10.4172/2155-9546.1000239

Page 2 of 5

\begin{tabular}{|l|c|c|c|c|}
\hline \multirow{2}{*}{ Ingredient } & \multicolumn{4}{|c|}{$\mathbf{g / 1 0 0} \mathbf{~ g}$} \\
\cline { 2 - 5 } & Control (0) & $\mathbf{5}$ & $\mathbf{1 0}$ & $\mathbf{2 0}$ \\
\hline White fish meal & 41 & 41 & 41 & 41 \\
\hline Casein & 20 & 15 & 10 & - \\
\hline Flounder skin meal (FSM) & - & 5 & 10 & 20 \\
\hline L-ascorbic acid & 0.02 & 0.02 & 0.02 & 0.02 \\
\hline Wheat flour & 22.58 & 23.28 & 23.98 & 25.28 \\
\hline Feed oil (squid liver oil) & 8.4 & 7.7 & 7 & 5.7 \\
\hline a-potato starch & 3 & 3 & 3 & 2 \\
\hline Vitamin premix ${ }^{1)}$ & 2 & 2 & 2 & 2 \\
\hline (vitamin C free) & & & & \\
\hline Mineral Premix ${ }^{2)}$ & 2 & 2 & 2 & 1 \\
\hline Choline Chloride & 1 & 1 & 1 & 1 \\
\hline Total & 100 & 100 & 100 & 100 \\
\hline Vitamin C in diets & 212.41 & 197.16 & 204.67 & 203.12 \\
\hline${ }^{*}$ Proximate analysis & & & & \\
\hline Protein & 46.71 & 47.21 & 47.11 & 46.11 \\
\hline Lipid & 9.21 & 9.51 & 10.11 & 10.81 \\
\hline Ash & 8.21 & 8.61 & 8.71 & 8.71 \\
\hline
\end{tabular}

${ }^{1)}$ Vitamin premix (mg/g mixture): retinol acetate, $0.81 \mathrm{mg}$; cholecalciferol 0.012 $\mathrm{mg}$; vitamin E, $22.5 \mathrm{mg}$; vitamin $\mathrm{K}_{3}, 2.5 \mathrm{mg}$, thiamine, $5.5 \mathrm{mg}$; riboflavin, $10 \mathrm{mg}$; pyridoxine, $6 \mathrm{mg}$; niacin, $37.5 \mathrm{mg}$; folic acid, $2 \mathrm{mg}$; biotin $0.05 \mathrm{mg}$; inositol $50 \mathrm{mg}$. All ingredients were diluted with alpha-cellulose to $1 \mathrm{~g}$.

${ }^{2}$ Mineral premix (mg/g mixture): Mn, $3.2 \mathrm{mg}$; Zn, $3.2 \mathrm{mg}$; Fe, $3.0 \mathrm{mg}$; Cu, $0.36 \mathrm{mg}$ $\mathrm{MgSO}_{4}, 100 \mathrm{mg} ; \mathrm{KCl}(47 \%), 60 \mathrm{mg} ; \mathrm{Al}(\mathrm{OH})_{3}, 1.06 \mathrm{mg} ; \mathrm{Ca}\left(\mathrm{IO}_{3}\right)_{2}, 0.475 \mathrm{mg} ; \mathrm{CoSO}_{4}$ $0.475 \mathrm{mg}$. All ingredients were diluted with alpha-cellulose to $1 \mathrm{~g}$.

*Dry matter

Table 1: Ingredient and proximate composition of experimental diets with various levels of FSM.

the nutritional composition of the prepared diets, and the vitamin $\mathrm{C}$ content of the diets were analyzed using the 2,4-dinitrophenyl hydrazine (DNP) colorimetric method [21].

FSM is a high protein meal containing more than $80 \%$ crude proteins but is lacking in essential amino acids compared to fishmeal. When fishmeal is replaced by FSM, unknown factors present in essential amino acids and fishmeal may affect the experimental fish, making it difficult to evaluate the influences of FSM substitution on experimental fish. Therefore, to maintain proper balances of the essential amino acids and to minimize the effects of the unknown factors in the fishmeal, white fishmeal (FF Skagen LT Supreme, Denmark) was fixed at the same level throughout the experimental diets. Casein, a purified protein, was used to control the protein content of each experimental diet. Squid liver oil (Ihwa, Korea) rich in DHA and EPA, which are essential fatty acids for the black rockfish, was used as a lipid source. Wheat flours (CJ, Korea) and $\alpha$-potato starch were employed as carbohydrate sources to control energy and bind the diets. To find the relationship between the level of vitamin C and FSM substitution on the fish body, vitamin C (200 mg/ $\mathrm{kg}$ ) was added based upon the vitamin $\mathrm{C}$ requirements of the black rockfish reported by Bai et al. [22]. There were a total of 4 experimental groups, including a control group with fishmeal and casein only and 3 experimental groups with 5,10 , or $20 \%$ of the casein replaced by FSM.

Analyzes of proximate composition, fatty acid, total amino acid, free amino acid, organic acid, and free sugar in this study were carried out based on AOAC methods [23] and some modifications of Hwang et al. [24].

All mean values were analyzed via one-way analysis of variance (ANOVA). When differences were found among data, Duncan's multiple range test was used to compare the mean difference by using the SPSS software package version 17 (Statistical Package for Social

Sciences, SPSS Inc., Chicago, IL, USA). Differences were considered significant at $\mathrm{p}<0.05$.

\section{Results}

Proximate compositions with various levels of FSM are shown in Table 2. Crude protein was significantly higher in the FSM groups than the control group. FSM 5\% was much higher than FSM 10\% and FSM $20 \%(\mathrm{P}<0.05)$. Crude lipid was significantly lower in the FSM groups than the control group, especially in FSM 20\% compared to that of FSM 5\% and FSM 10\% $(\mathrm{P}<0.05)$.

The fatty acid composition of the whole body is shown in Table 3. Saturates were observed to be significantly lower in all FSM groups than the control group $(\mathrm{P}<0.05)$, and no significant differences were found in monoenes $(\mathrm{P}<0.05)$. Significantly higher polyenes were observed in the FSM groups than the control group, especially in FSM $20 \%(\mathrm{P}<0.05)$. The control group was also significantly lower in $\mathrm{n}-3$ than FSM $5 \%$ and FSM $20 \%(\mathrm{P}<0.05)$, whereas FSM $10 \%$ was not significantly different from the control group. There were no significant differences in $n-6$ between the experimental groups. The $n-3 / n-6$ ratio was not significantly different between the control group and FSM 5\% and FSM $10 \%$, while FSM $20 \%$ was significantly higher than the control group $(\mathrm{P}<0.05)$.

The whole-body amino acid contents are shown in Table 4 . The total amino acids and EAA were significantly higher in FSM 20\% than the other groups $(\mathrm{P}<0.05)$. FSM $20 \%$ was significantly higher in all amino acids compared to the control group $(\mathrm{P}<0.05)$, whereas FSM $5 \%$ and FSM 10\% were not significantly different from the control group.

The whole-body free amino acid contents are shown in Table 5. The total free amino acids were significantly lower in the FSM groups than the control group, and the FSM groups tended to decreased significantly in a dose-dependent manner $(\mathrm{P}<0.05)$.

Seven kinds of free sugars were analyzed, and fucose, rhamnose, glucose, mannose, fructose, and ribose were detected but not galactose (Table 6). The total free sugars were not significantly different in the control group, FSM 5\%, and FSM 10\%, while they were significantly lower in FSM 20\% $(\mathrm{P}<0.05)$.

Six kinds of organic acids were analyzed, and lactic acid, oxalic acid, and citric acid were found, but not malic acid, tartaric acid, or maleic acid (Table 7). The total organic acid content was significantly lower in the FSM groups than the control group $(\mathrm{P}<0.05)$.

\section{Discussion}

In the previous result, it was confirmed that there was a high collagen content (approximately 20\% dry weight) in Paralichthys olivaceus skin [25]. Flounder skin meal (FSM) replaced various fractions of the casein

\begin{tabular}{|l|c|c|c|c|}
\hline $\begin{array}{l}\text { Proximate } \\
\text { composition } \\
\mathbf{( g / 1 0 0 ~ g ) ~}\end{array}$ & \multicolumn{3}{|c|}{ FSM substitution level (\%) } \\
\cline { 3 - 5 } & Control (0) & $\mathbf{5}$ & $\mathbf{1 0}$ & $\mathbf{2 0}$ \\
\hline Moisture & $68.14 \pm 1.28^{\mathrm{a}}$ & $67.93 \pm 0.47^{\mathrm{a}}$ & $68.73 \pm 0.05^{\mathrm{ab}}$ & $69.54 \pm 0.07^{\mathrm{b}}$ \\
\hline Crude protein & $14.28 \pm 0.07^{\mathrm{a}}$ & $15.10 \pm 0.03^{\mathrm{d}}$ & $14.75 \pm 0.08^{\mathrm{b}}$ & $14.93 \pm 0.04^{\mathrm{c}}$ \\
\hline Crude lipid & $10.53 \pm 0.22^{\mathrm{c}}$ & $9.72 \pm 0.02^{\mathrm{b}}$ & $9.20 \pm 0.25^{\mathrm{b}}$ & $8.25 \pm 0.53^{\mathrm{a}}$ \\
\hline Ash & $3.77 \pm 0.07^{\mathrm{a}}$ & $4.11 \pm 0.08^{\mathrm{c}}$ & $3.92 \pm 0.08^{\mathrm{b}}$ & $4.04 \pm 0.03^{\mathrm{bc}}$ \\
\hline
\end{tabular}

Data are mean \pm SD. Values with different superscripts are significantly different $(P<0.05)$.

${ }^{\mathrm{n}}$ Not significant.

Table 2: Proximate composition (\%) of whole body in black rockfish (S. schlegeli) fed the test diets with various levels of FSM for 8 weeks. 
Citation: Rha SJ, Cho JK, Kim SJ, Park WM, Shin TS, et al. (2014) Nutritional Characteristics of Black Rockfish (Sebastes schlegeli) Fed a Diet of Fish Skin. J Aquac Res Development 5: 239 doi:10.4172/2155-9546.1000239

\begin{tabular}{|c|c|c|c|c|}
\hline \multirow[t]{2}{*}{ Fatty acid } & \multicolumn{4}{|c|}{ FSM substitution level (\%) } \\
\hline & Control (0) & 5 & 10 & 20 \\
\hline C12:0 & $0.31 \pm 0.01^{d}$ & $26 \pm 0.01^{\circ}$ & $0.24 \pm 0.01^{b}$ & $.19 \pm 0.00^{\mathrm{a}}$ \\
\hline C13:0 & $.05 \pm 0.01^{\text {ns }}$ & $5 \pm 0.00$ & $05 \pm 0.00$ & $0.05 \pm .00$ \\
\hline C14:0 & $7.42 \pm 0.05^{\mathrm{b}}$ & $6.91 \pm 0.23^{a}$ & $7.14 \pm 0.17^{\mathrm{ab}}$ & $7.33 \pm 0.07^{b}$ \\
\hline C15:0 & $0.96 \pm 0.07^{\mathrm{a}}$ & $1.00 \pm 0.02^{\mathrm{ab}}$ & $1.00 \pm 0.01^{\mathrm{ab}}$ & $1.04 \pm 0.02^{b}$ \\
\hline C16:0 & $24.07 \pm 0.06^{\mathrm{b}}$ & $23.23 \pm 0.46^{a}$ & $23.69 \pm 0.22^{\mathrm{ab}}$ & $23.44 \pm 0.15^{\mathrm{a}}$ \\
\hline C17:0 & $79 \pm 0$ & $79 \pm 0.00^{\circ}$ & $.75 \pm c$ & $0.72 \pm 0.02^{\mathrm{a}}$ \\
\hline C18:0 & $69 \pm 0.10^{b}$ & $31 \pm 0.13^{b}$ & $63 \pm 0.16^{b}$ & $.24 \pm 0.07^{a}$ \\
\hline $\mathrm{C} 20: 0$ & $1.64 \pm 0.04^{\circ}$ & $1.03 \pm 0.03^{b}$ & $96 \pm 0.02^{\mathrm{a}}$ & $0.92 \pm 0.05^{\mathrm{a}}$ \\
\hline $\mathrm{C} 21: 0$ & $0.57 \pm 0.02^{\mathrm{ns}}$ & $0.56 \pm 0.11$ & $.55 \pm 0.01$ & $0.50 \pm 0.05$ \\
\hline $\mathrm{C} 22: 0$ & $0.81 \pm 0.01^{\mathrm{a}}$ & $0.81 \pm 0.01^{\mathrm{a}}$ & $0.76 \pm 0.01^{b}$ & $\pm 0.01^{\mathrm{a}}$ \\
\hline C23:0 & $1.12 \pm 0.02^{\mathrm{a}}$ & $1.25 \pm 0$ & $3^{c}$ & $1.55 \pm 0.03^{d}$ \\
\hline $\mathrm{C} 24: 0$ & $43 \pm$ & $50 \pm 0$ & ab & $1.47 \pm$ \\
\hline Saturate & $45.87 \pm 0.23^{b}$ & $44.21 \pm 0.60^{\mathrm{a}}$ & $44.58 \pm 0.21^{\mathrm{a}}$ & $44.18 \pm$ \\
\hline C14:1 & $0.32 \pm 0.01^{d}$ & $0.27 \pm 0.01^{a}$ & $0.30 \pm 0.01^{b}$ & $0.31 \pm 0.00^{c}$ \\
\hline C15:1 & $0.02 \pm 0.00^{\text {ns }}$ & $0.02 \pm 0.00$ & $02 \pm 0.00$ & $0.02 \pm$ \\
\hline C16:1 & $6.29 \pm 0.03^{b}$ & $5.99 \pm 0.10^{\mathrm{a}}$ & $6.33 \pm 0.02^{b}$ & $6.46 \pm 0.07^{c}$ \\
\hline C17:1 & $5 \pm 0.01^{a}$ & $0.45 \pm 0.01^{\mathrm{a}}$ & $0.46 \pm 0.00^{\mathrm{a}}$ & $.49 \pm 0.01^{b}$ \\
\hline C18:1n9 & $0.53 \pm 0.19^{\mathrm{ns}}$ & $37 \pm 0.17$ & $0.46 \pm .12$ & $0.39 \pm 0.10$ \\
\hline $\mathrm{C} 18: 1 \mathrm{n} 9 \mathrm{c}$ & $20.43 \pm 0.15^{b}$ & $20.45 \pm 0.25^{b}$ & $20.40 \pm$ & 19.89 \\
\hline $\mathrm{C} 20: 1$ & $4.65 \pm 0.11^{\mathrm{ab}}$ & $5.15 \pm 0.34^{b}$ & $4.72 \pm 0.51^{\mathrm{ab}}$ & $4.23 \pm 0.20^{a}$ \\
\hline C22:1n9 & $0.96 \pm 0.01^{a}$ & $0.97 \pm 0.01^{\mathrm{ab}}$ & $0.99 \pm 0.01^{b c}$ & $0.99 \pm 0.01^{c}$ \\
\hline $\mathrm{C} 24: 1$ & $0.89 \pm 0.11^{\text {ns }}$ & $1.06 \pm 0.17$ & $04 \pm 0.17$ & $1.14 \pm 0.16$ \\
\hline Monoen & $34.55 \pm 0.28^{\text {ns }}$ & $34.73 \pm 0.52$ & $34.71 \pm$ & 33.92 \\
\hline $\mathrm{C} 18: 2 \mathrm{n} 6 \mathrm{t}$ & $0.17 \pm 0.0$ & $17 \pm 0.01$ & $17 \pm 0.01$ & $0.12 \pm 0.08$ \\
\hline C18:2n6c & $0.43 \pm 0.01^{\mathrm{ns}}$ & $42 \pm 0.01$ & $43 \pm 0.01$ & $0.43 \pm 0.01$ \\
\hline $\mathrm{C} 20: 2$ & $0.77 \pm 0.00^{\mathrm{a}}$ & $0.83 \pm 0.02^{b}$ & $0.78 \pm 0.02^{a}$ & $0.76 \pm 0.02^{\mathrm{a}}$ \\
\hline C22:2 & $0.07 \pm 0.01^{\mathrm{a}}$ & $0.11 \pm 0.01^{b}$ & $0.10 \pm 0.02^{\mathrm{ab}}$ & $0.09 \pm 0.02^{\mathrm{ab}}$ \\
\hline C18:3n6 & $0.33 \pm 0.01^{\mathrm{a}}$ & $0.36 \pm 0.01^{b}$ & $0.33 \pm .01^{\mathrm{a}}$ & $0.35 \pm 0.01^{b}$ \\
\hline C18:3r & $1.31 \pm 0.01^{\text {ns }}$ & $32 \pm 0.04$ & $30 \pm 0.02$ & $1.30 \pm 0.01$ \\
\hline $\mathrm{C} 20: 3 \mathrm{n} 6$ & $0.03 \pm 0.01^{\mathrm{ns}}$ & $2 \pm 0.00$ & $02 \pm 0.00$ & .01 \\
\hline $\mathrm{C} 20: 3 \mathrm{n} 3$ & $0.15 \pm$ & $17 \pm 0$ & $15 \pm 0.01$ & $0.16 \pm 0.02$ \\
\hline C20:4n6 & $0.26 \pm 0.00^{\mathrm{a}}$ & $0.28 \pm 0.01^{b}$ & $0.29 \pm 0.00^{c}$ & $0.31 \pm 0.00^{d}$ \\
\hline $\mathrm{C} 20: 5 \mathrm{n} 3$ & $0.00 \pm 0.00^{\mathrm{a}}$ & $0.28 \pm 0.08^{c}$ & $0.19 \pm 0.02^{b}$ & $0.18 \pm 0.02^{b}$ \\
\hline $\mathrm{C} 22: 6 \mathrm{n} 3$ & $16.04 \pm 0.47^{\mathrm{a}}$ & $17.09 \pm 0.87^{\mathrm{ab}}$ & $16.95 \pm 0.42^{\mathrm{a}}$ & $18.17 \pm 0.40^{b}$ \\
\hline Polyene & $19.57 \pm 0.47^{\mathrm{a}}$ & $21.06 \pm 0.87^{b}$ & $20.71 \pm 0$ & $21.91 \pm 0.47^{\circ}$ \\
\hline n3 & 17.5 & $18.87 \pm 0.88^{\mathrm{bc}}$ & $18.59 \pm 0.45^{\mathrm{ab}}$ & $19.82=$ \\
\hline n6 & $1.22 \pm 0.01^{\mathrm{ns}}$ & $1.25 \pm 0.03$ & $1.24 \pm 0.02$ & $1.24 \pm 0.08$ \\
\hline$n 3 / n 6$ & $14.31 \pm 0.33^{a}$ & $15.07 \pm 1.00^{\mathrm{ab}}$ & $15.04 \pm 0.52^{\mathrm{ab}}$ & $16.06 \pm 0.73^{b}$ \\
\hline
\end{tabular}

Data are mean $\pm \mathrm{SD}$. Values with different superscripts are significantly different $(P<0.05)$.

${ }^{n}$ Not significant.

Table 3: Fatty acid composition of whole body in black rockfish (S. schlegeli) fed the test diets with various levels of FSM for 8 weeks $(\mathrm{g} / 100 \mathrm{~g})$.

substitution in the fishmeal, and this was fed to the fish for 8 weeks to confirm the substitution effect.

Comparing the results of such fishmeal substitution is difficult because of the various protein sources and fish utilized. However, the nutritional characteristics of the alternative protein sources affect lipid metabolism in the body. In particular, as FSM contains relatively higher lipid content (17\%) compared to white and brown fishmeal (7$8 \%$ ), it would affect lipid accumulation and metabolism. In the FSM substitution group, the protein content in the whole body increased and the lipid content decreased, and the ash content increased significantly compared to the control group. The body composition of fish is affected by various factors such as intraspecific strain differences, water temperature, and increased body weight, and is influenced the most by the amount of feed supplied and the mix proportions of the feed $[26,27]$.
Among whole-body fatty acid responses to the FSM substitution in the feed, saturated fatty acids significantly decreased while polyunsaturated fatty acids increased, especially n-3 HUFA, which is an essential fatty acid in black rockfish [28]. The white fishmeal used in this study contained about $0.7 \%$ n-3 HUFA, and fish oil, like the squid liver oil used as a lipid source, has more than $20 \%$ n-3 HUFA with an appropriate EPA/DHA ratio [29]. Accumulation of n-3 HUFA in fish bodies increased because of the FSM substitution. This seems to be because of FSM-specific amino acids rather than the differences in n-3 HUFA in the feed.

Amino acids in fish were significantly higher only in FSM $20 \%$ than the control group. Although such differences may occur due to the FSM substitution, this is not certain because significant differences in the amino acids were not observed between the control group and the experimental groups. However, the free amino acids in the fish body were significantly decreased in the FSM groups compared to the control group, suggesting that the FSM substitution influenced amino acid metabolism in the fish. In marine animals, free amino acids provide chemical signals for behaviors, communication, and metabolism through sensory organs [30]. Moreover, free amino acids act as substrates for protein biosynthesis or aerobic catabolism and provide osmolality stably during embryonic stages through intrinsic nutrients in marine fish [31,32].

Lactic acids were the most abundant organic acids, especially in the FSM substitution groups. Lactic acids are known to greatly differ based on the amount of activity at the time of harvesting and the storage conditions [33]. However, lactic acids showed significant differences in the FSM substitution group compared to the control group in the present study. Given that the amount of activity at the time of harvesting and storage conditions were similar in this study, lactic acids seem to have an influence on the energy metabolism of glycolysis with respect

\begin{tabular}{|c|c|c|c|c|}
\hline & \multicolumn{4}{|c|}{ FSM substitution level (\%) } \\
\hline & Control (0) & 5 & 10 & 20 \\
\hline Aspatic acid & $2.97 \pm 0.07^{a}$ & $3.20 \pm 0.30^{\mathrm{a}}$ & $3.17 \pm 0.04^{a}$ & $3.58 \pm 0.12^{b}$ \\
\hline *Threonine & $1.54 \pm 0.05^{\mathrm{a}}$ & $1.66 \pm 0.16^{\mathrm{ab}}$ & $1.73 \pm 0.21^{\mathrm{ab}}$ & $1.82 \pm 0.04^{b}$ \\
\hline Serine & $1.85 \pm 0.06^{\mathrm{a}}$ & $2.02 \pm 0.19^{a b}$ & $2.01 \pm 0.10^{\mathrm{ab}}$ & $2.23 \pm 0.07^{b}$ \\
\hline Glutamic acid & $3.78 \pm 0.09^{a}$ & $4.12 \pm 0.39^{a}$ & $4.08 \pm 0.15^{a}$ & $4.60 \pm 0.16^{b}$ \\
\hline Proline & $1.59 \pm 0.03^{a}$ & $1.73 \pm 0.17^{a}$ & $1.67 \pm 0.06^{\mathrm{a}}$ & $1.97 \pm 0.09^{b}$ \\
\hline Glycine & $4.37 \pm 0.11^{\mathrm{a}}$ & $4.89 \pm 0.45^{\mathrm{a}}$ & $4.58 \pm 0.11^{\mathrm{a}}$ & $5.62 \pm 0.33^{b}$ \\
\hline Alanine & $3.11 \pm 0.09^{a}$ & $3.41 \pm 0.31^{a}$ & $3.18 \pm 0.10^{\mathrm{a}}$ & $3.79 \pm 0.17^{b}$ \\
\hline Cystine & $0.11 \pm 0.00^{\mathrm{a}}$ & $0.12 \pm 0.03^{a b}$ & $0.13 \pm 0.01^{\mathrm{ab}}$ & $0.15 \pm 0.01^{\mathrm{b}}$ \\
\hline *Valine & $1.61 \pm 0.05^{a}$ & $1.74 \pm 0.18^{\mathrm{ab}}$ & $1.74 \pm 0.03^{\mathrm{ab}}$ & $1.93 \pm 0.06^{b}$ \\
\hline *Methionine & $0.81 \pm 0.02^{\mathrm{a}}$ & $0.86 \pm 0.10^{\mathrm{a}}$ & $0.86 \pm 0.01^{\mathrm{a}}$ & $0.97 \pm 0.03^{b}$ \\
\hline *Isoleucine & $1.23 \pm 0.02^{\mathrm{a}}$ & $1.32 \pm 0.13^{a}$ & $1.31 \pm 0.01^{\mathrm{a}}$ & $1.46 \pm 0.04^{b}$ \\
\hline *Leucine & $2.22 \pm 0.05^{a}$ & $2.37 \pm 0.23^{a}$ & $2.34 \pm 0.01^{\mathrm{a}}$ & $2.60 \pm 0.07^{b}$ \\
\hline *Tyrosine & $0.57 \pm 0.03^{a}$ & $0.61 \pm 0.11^{\mathrm{a}}$ & $0.67 \pm 0.04^{a}$ & $0.76 \pm 0.01^{b}$ \\
\hline *Phenylalanine & $0.96 \pm 0.02^{\mathrm{a}}$ & $1.07 \pm 0.11^{\mathrm{a}}$ & $1.04 \pm 0.05^{a}$ & $1.19 \pm 0.04^{b}$ \\
\hline *Histidine & $0.81 \pm 0.02^{\mathrm{a}}$ & $0.91 \pm 0.07^{b}$ & $0.86 \pm 0.01 b^{a}$ & $0.93 \pm 0.02^{b}$ \\
\hline *Lysine & $1.72 \pm 0.04^{a}$ & $1.86 \pm 0.21^{\mathrm{a}}$ & $1.94 \pm 0.03^{a}$ & $2.25 \pm 0.08^{b}$ \\
\hline Ammonia & $2.28 \pm 0.05^{a}$ & $2.42 \pm 0.17^{\mathrm{ab}}$ & $2.32 \pm 0.07^{a}$ & $2.58 \pm 0.11^{b}$ \\
\hline${ }^{*}$ Arginine & $1.42 \pm 0.04^{a}$ & $1.48 \pm 0.18^{a}$ & $1.52 \pm 0.02^{\mathrm{a}}$ & $1.76 \pm 0.07^{\mathrm{b}}$ \\
\hline Total & $32.96 \pm 0.82^{\mathrm{a}}$ & $35.80 \pm 3.44^{\mathrm{a}}$ & $35.17 \pm 0.76^{a}$ & $40.18 \pm 1.49^{b}$ \\
\hline${ }^{*} \mathrm{EAA}$ & $12.32 \pm 0.31^{a}$ & $13.28 \pm 1.35^{a}$ & $13.35 \pm 0.34^{a}$ & $14.90 \pm 0.45^{b}$ \\
\hline
\end{tabular}

Data are mean \pm SD. Values with different superscripts are significantly different $(P<0.05)$.

${ }^{n s}$ Not significant.

Essential amino acid.

Table 4: Total amino acid content of whole body in black rockfish (S. schlegeli) fed the test diets with various levels of FSM for 8 weeks $(g / 100 \mathrm{~g})$. 
Citation: Rha SJ, Cho JK, Kim SJ, Park WM, Shin TS, et al. (2014) Nutritional Characteristics of Black Rockfish (Sebastes schlegeli) Fed a Diet of Fish Skin. J Aquac Res Development 5: 239 doi:10.4172/2155-9546.1000239

Page 4 of 5

\begin{tabular}{|c|c|c|c|c|}
\hline & \multicolumn{3}{|c|}{ FSM substitution level (\%) } & \multirow[b]{2}{*}{20} \\
\hline & Control (0) & 5 & 10 & \\
\hline Phosphoserine & $0.77 \pm 0.03^{b}$ & $0.84 \pm 0.01^{\circ}$ & $0.78 \pm 0.02^{b}$ & $0.62 \pm 0.0$ \\
\hline Taurine & $3.31 \pm 0.04^{a}$ & $3.27 \pm 0.17^{a}$ & $3.41 \pm 0.04^{\mathrm{a}}$ & $3.57 \pm 0.09^{b}$ \\
\hline Aspartic acid & $3.31 \pm 0.02^{\mathrm{d}}$ & $2.51 \pm 0.02^{\circ}$ & $1.61 \pm 0.04^{b}$ & $1.35 \pm 0.02^{\mathrm{a}}$ \\
\hline Hydroxyproline & $1.68 \pm 0.05^{b}$ & $1.23 \pm 0.27^{\mathrm{a}}$ & $1.89 \pm 0.13^{b}$ & $1.70 \pm 0.18^{b}$ \\
\hline Threonine & $3.18 \pm 0.04^{a}$ & $2.26 \pm 0.06^{\mathrm{b}}$ & $1.54 \pm 0.05^{c}$ & $1.13 \pm 0.02^{\mathrm{d}}$ \\
\hline Serine & $2.19 \pm 0.02^{\mathrm{d}}$ & $1.84 \pm 0.09^{c}$ & $1.39 \pm 0.04^{b}$ & $0.91 \pm 0.02^{\mathrm{a}}$ \\
\hline Asparagine & $0.88 \pm 0.06^{\mathrm{b}}$ & $0.30 \pm$ & $0.30=$ & $0.31 \pm$ \\
\hline Glutamic acid & $5.46 \pm 0.10^{d}$ & $3.91 \pm$ & $2.57 \pm 0.07^{b}$ & $2.36 \pm 0.05^{\mathrm{a}}$ \\
\hline Proline & $1.95 \pm 0.04^{d}$ & $1.51 \pm$ & $1.19 \pm$ & $0.75 \pm$ \\
\hline Glycine & $2.75 \pm 0.03^{c}$ & $2.97 \pm$ & $2.57 \pm$ & $2.38 \pm 0.01^{a}$ \\
\hline Alanine & $5.95 \pm 0.05^{d}$ & $4.92 \pm c$ & $3.79 \pm$ & $3.02 \pm 0.01^{a}$ \\
\hline Citrulline & $0.34 \pm 0.03^{d}$ & $0.22 \pm c$ & $0.11 \pm$ & $0.05 \pm 0.00^{\mathrm{a}}$ \\
\hline Valine & $3.10 \pm 0.02^{\mathrm{d}}$ & $2.07 \pm$ & $1.53 \pm$ & $0.99 \pm 0.02^{\mathrm{a}}$ \\
\hline Methionine & $0.86 \pm 0.02^{\mathrm{d}}$ & $0.48 \pm$ & $0.41 \pm 0.02^{b}$ & $0.32 \pm 0.02^{\mathrm{a}}$ \\
\hline Isoleucine & $2.46 \pm 0.01^{d}$ & $1.62 \pm$ & $1.10 \pm 0.04^{b}$ & $0.73 \pm 0.01^{a}$ \\
\hline Leucine & $7.33 \pm 0.01^{d}$ & $4.33 \pm$ & $3.34 \pm$ & $2.54 \pm 0.01^{a}$ \\
\hline Tyrosine & $1.35 \pm 0.06^{b}$ & $1.62 \pm 0.06^{\circ}$ & $1.44 \pm 0.06^{b}$ & $0.99 \pm 0.03^{a}$ \\
\hline Phenylalanine & $2.84 \pm 0.01^{d}$ & $1.61 \pm 0.02^{\circ}$ & $1.33 \pm 0.03^{b}$ & $0.95 \pm 0.01^{a}$ \\
\hline$\beta$-aminoisobutyric acid & $1.06 \pm 0.07^{b}$ & $0.53 \pm$ & $0.61 \pm$ & $0.55 \pm 0.03^{a}$ \\
\hline Y-amino-n-butyric acid & $0.03 \pm 0.01^{b}$ & $0.01 \pm$ & $0.01 \pm$ & $0.02 \pm 0.00^{\mathrm{ab}}$ \\
\hline Histidine & $0.95 \pm 0.01^{d}$ & $0.56 \pm$ & $0.45 \pm$ & $0.20 \pm 0.01^{a}$ \\
\hline 1-methylhistidine & $0.06 \pm 0.00^{b}$ & $0.03 \pm 0$ & $0.02 \pm 0.00^{\mathrm{a}}$ & $0.01 \pm 0.01^{a}$ \\
\hline Carnosine & $0.21 \pm 0.01^{c}$ & 0.13 & $0.14 \pm$ & $0.07 \pm 0.02^{\mathrm{a}}$ \\
\hline Anserine & $0.29 \pm 0.06^{\mathrm{ns}}$ & $0.29 \pm 0.05$ & $0.31 \pm$ & $0.32 \pm 0.01$ \\
\hline Tryptopan & $0.51 \pm 0.09^{b}$ & $0.22 \pm 0.08^{\mathrm{a}}$ & $0.17 \pm 0.07^{\mathrm{a}}$ & $0.09 \pm 0.04^{a}$ \\
\hline Hydroxylysi & $0.11 \pm 0.01^{b}$ & $0.05 \pm 0.01^{a}$ & $0.04 \pm 0.01^{\mathrm{a}}$ & $0.05 \pm 0.02^{\mathrm{a}}$ \\
\hline Ornitine & $0.19 \pm 0.01^{\circ}$ & $0.09 \pm 0.01^{b}$ & $0.06 \pm 0.01^{\mathrm{a}}$ & $0.06 \pm 0.00^{\mathrm{a}}$ \\
\hline Lysine & $2.99 \pm 0.07^{d}$ & $0.77 \pm 0.03^{\circ}$ & $0.49 \pm 0.02^{b}$ & $0.33 \pm 0.02^{\mathrm{a}}$ \\
\hline Ammonia & $2.20 \pm 0.03^{c}$ & $1.86 \pm 0.16^{a}$ & $1.42 \pm 0.03^{\mathrm{a}}$ & $1.55 \pm 0.02^{b}$ \\
\hline Ethanolamine & $0.36 \pm 0.08^{\text {ns }}$ & $0.40 \pm 0.03$ & $0.34 \pm 0.03$ & $0.38 \pm 0.04$ \\
\hline Arginine & $8.71 \pm 0.12^{\mathrm{d}}$ & $5.84 \pm 0.18^{c}$ & $5.25 \pm 0.16^{b}$ & $3.57 \pm 0.05^{\mathrm{a}}$ \\
\hline Total & $67.37 \pm 0.26^{d}$ & $48.31 \pm 0.99^{\circ}$ & $39.61 \pm 1.29^{b}$ & $31.88 \pm 0.22^{\mathrm{a}}$ \\
\hline
\end{tabular}

to the FSM substitution.

The glucose content in the free sugars was significantly higher in FSM $5 \%$ and FSM $10 \%$ than the control group; but no significant differences between control and FSM 20\%, indicating that FSM substitution affect glucose metabolism, resulting in differences in body glucose. Ribose differed in a similar manner, leading to glucose levels decreased in response to the FSM substitution. Free ribose is abundant in the muscles of living fish but is also released from inosine, which is produced by ATP decomposition after death. Consequently, ribose content can depend on the pretreatment conditions of the samples immediately after the instant killing [1]. As ribose, along with fructose, is a quantitatively important factor in glycolysis, it is considered to be somewhat associated with glucose metabolism.

\section{Acknowledgments}

This research was supported by Basic Science Research Program through the National Research Foundation of Korea (NRF) funded by the Ministry of Education, Science and Technology (2011-0011204).

\section{References}

1. Kim HY, Kim EH, Kim DH, Oh MJ, Shin TS (2009) The Nutritional Components of Olive Flounder (Paralichthys olivaceus) Fed Diets with Yuza (Citrus junos Sieb Ex Tnaka). Kor J Fish Aquat Sci 42: 215-223.

2. Lee SM, Jeon IG (1996) Evaluation of Soybean Meal as a Partial Substitute for Fish Meal in Formulated Diets for Korean Rockfish, Sebastes schlegeli. Kor J Fish Soc 29: 586-594.

3. Murai T, Akiyama T, Hirasawa Y, Oshiro T, Okauchi M, et al. (1982) Blood Constituent Levels and Body Composition of Wild and Cultured Bluefin Tuna Juveniles. Bull Natl Res Inst Aquaculture 3: 51-59.

4. Robert CR, Braden SL, Laprarie RJ (1993) Substitution of Soybean Protein for Fish Protein in Formulated Diets for Red Swamp Crawfish Procambarus clarkii. J World Aquacult Soc 24: 329-338.

5. Lee SM, Yoo JH (1996) Evaluation of Cotton Seed Meal or Rapeseed Mea as a Partial Substitute for Fish Meal in Fotmulated Diets for Korean Rockfish (Sebastes schlegeli). Kor J Anim Nutr Feed 20: 128-135.

$(P<0.05)$

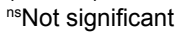

Table 5: Free amino acid content of whole body in black rockfish (S. schlegeli) fed the test diets with various levels of FSM for 8 weeks $(\mathrm{g} / 100 \mathrm{~g})$.

FSM substitution level (\%)

\begin{tabular}{|l|c|c|c|c|}
\hline \multirow{2}{*}{} & \multicolumn{4}{|c|}{ FSM substitution level (\%) } \\
\cline { 2 - 5 } & Control (0) & $\mathbf{5}$ & $\mathbf{1 0}$ & $\mathbf{2 0}$ \\
\hline Fucose & $150.20 \pm 15.39^{\mathrm{n}}$ & $155.82 \pm 10.22$ & $132.53 \pm 14.89$ & $145.44 \pm 15.64$ \\
\hline Rhamnose & $354.54 \pm 35.57^{\mathrm{d}}$ & $284.62 \pm 27.03^{\mathrm{c}}$ & $136.03 \pm 32.66^{\mathrm{b}}$ & $82.35 \pm 0.55^{\mathrm{a}}$ \\
\hline Glucose & $280.99 \pm 5.25^{\mathrm{a}}$ & $424.50 \pm 31.76^{\mathrm{b}}$ & $464.12 \pm 27.22^{\mathrm{b}}$ & $289.80 \pm 19.75^{\mathrm{a}}$ \\
\hline Mannose & $190.91 \pm 11.39^{\mathrm{a}}$ & $217.63 \pm 32.91^{\mathrm{a}}$ & $319.56 \pm 14.43^{\mathrm{b}}$ & $207.09 . \pm 17.14^{\mathrm{a}}$ \\
\hline Fructose & $76.05 \pm 8.64^{\mathrm{a}}$ & $87.12 \pm 2.18^{\mathrm{ab}}$ & $105.61 \pm 7.69^{\mathrm{bc}}$ & $109.35 \pm 15.86^{\mathrm{c}}$ \\
\hline Ribose & $81.90 \pm 6.05^{\mathrm{c}}$ & $75.70 \pm 7.02^{\mathrm{bc}}$ & $65.63 \pm 4.73^{\mathrm{b}}$ & $49.10 \pm 7.70^{\mathrm{a}}$ \\
\hline Total & $1,134.59 \pm 82.29^{\mathrm{b}}$ & $1,245.38 \pm 111.11^{\mathrm{b}}$ & $1,223.49 \pm 101.61^{\mathrm{b}}$ & $883.14 \pm 76.63^{\mathrm{a}}$ \\
\hline
\end{tabular}

Data are mean $\pm \mathrm{SD}$. Values with different superscripts are significantly different $(P<0.05)$.

ns Not significant.

Table 6: Free sugar content of whole body in black rockfish (S. schlegeli) fed the test diets with various levels of FSM for 8 weeks $(\mathrm{mg} / \mathrm{L})$.

\begin{tabular}{|l|c|c|c|c|}
\hline \multirow{2}{*}{} & \multicolumn{3}{|c|}{ FSM substitution level (\%) } \\
\cline { 2 - 5 } & Control (0) & $\mathbf{5}$ & $\mathbf{1 0}$ & $\mathbf{2 0}$ \\
\hline Lactic acid & $12.12 \pm 0.34^{\mathrm{c}}$ & $10.11 \pm 0.09^{\mathrm{b}}$ & $7.79 \pm 1.63^{\mathrm{a}}$ & $9.09 \pm 0.13^{\mathrm{ab}}$ \\
\hline Oxalic acid & $0.19 \pm 0.01^{\mathrm{b}}$ & $0.15 \pm 0.02^{\mathrm{a}}$ & $0.13 \pm 0.01^{\mathrm{a}}$ & $0.15 \pm 0.03^{\mathrm{a}}$ \\
\hline Citric acid & $0.72 \pm 0.03^{\mathrm{a}}$ & $0.68 \pm 0.02^{\mathrm{ab}}$ & $0.65 \pm 0.03^{\mathrm{a}}$ & $0.71 \pm 0.02^{\mathrm{b}}$ \\
\hline Total & $13.03 \pm 0.12^{\mathrm{c}}$ & $10.90 \pm 0.18^{\mathrm{b}}$ & $8.57 \pm 1.60^{\mathrm{a}}$ & $9.95 \pm 0.16^{\mathrm{ab}}$ \\
\hline
\end{tabular}

Data are mean \pm SD. Values with different superscripts are significantly different $(P<0.05)$.

ns Not significant.

Table 7: Organic acid content of whole body in black rockfish (S. schlegeli) fed the test diets with various levels of FSM for 8 weeks $(\mathrm{mg} / \mathrm{L})$.
6. Pham AM, Lee KJ, Lim SJ, Lee BJ, Kim SS, et al. (2005) Fish Mea Replacement by Cottonseed and Soybean Meal in Diets for Juvenile Olive Flounder, Paralichthys olivaceus. J Aquacult 18: 515-221.

7. Rena KJ, Hasan MR (2009) Impact of Rising Feed Ingredient Prices on Aquafeeds and Aquaculture Production. FAO Fisheries and Aquaculture Technical Paper 541: 1-7.

8. Ai Q, Mai K, Tan B, Xu W, Duan Q, Ma H, Zhang L (2006) Replacement of Fish Meal by Meat and Bone Meal in Diets for Large Yellow Croaker, Pseudosciaena crocea. Aquaculture 260: 255-263.

9. Bai SC, Jang HK, Cho ES (1998) Possible Use of the Animal By-Product Mixture as a Dietary Fish Meal Replace in Growing Common Carp (Cyprinus carpio). Kor J Fish Soc 31: 380-385

10. Kikuchi K, Honda H, Kiyono M (1994) Utilization of Feather Meal also a Protein Source in the Diet of Juvenile Japanese Flounder. Fish Sci 60: 203-306.

11. Kim KW, Bai SC (1999) Possible Use of the Dietary Fish Meal Analogue in Juvenile Korean Rockfish, Sebastes schlegeli. J Korean Fish Soc 32: 149-154.

12. Lee JK, Lee SM Lee (1998) Evaluation of Soybean Meal or Feather Meal as a Partial Substitute for Fish Meal in Formulated Diets for Fat Cod (Hexagrammos otakii Jordan at Starks). J Aquacult 11: 421-428.

13. Sato T, Kikuchi K (1997) Meat Meal as a Protein Source in the Diet of Juvenile Japanese Flounder. Fish Sci 63: 877-880

14. Cruz-Suárez LE, Ricque-Marie $D$, Martínez-Vega JA, Wesche-Fbeling $P$ (1993) Evaluation of Two Shrimp By-Product Meals as Protein Sources in Diets for Penaeus vannamei. Aquacult 115: 53-62.

15. Uyan O, Koshio S, Teshima S, Ishikawa M, Thu M, et al. (2006) Growth and Phosphorus Loading by Partially Replacing Fishmeal with Tuna Muscle ByProduct Powder in the Diet of Juvenile Japanese Flounder, Paralichthys olivaceus. Aquacult 257: 437-445. 
Citation: Rha SJ, Cho JK, Kim SJ, Park WM, Shin TS, et al. (2014) Nutritional Characteristics of Black Rockfish (Sebastes schlegeli) Fed a Diet of Fish Skin. J Aquac Res Development 5: 239 doi:10.4172/2155-9546.1000239

Page 5 of 5

16. Li P, Wang X, Hardy RW, Gatlin DM III (2004) Nutritional Value of Fisheries By-Catch and By-Product Meals in the Diet of Red Drum (Sciaenops ocellatus). Aquacult 236: 485-496.

17. Goytortúa-Bores E, Civera-Cerecedo R, Rocha-Meza S, Green-Yee A (2006) Partial Replacement of Red Crab (Pleuroncodes planipes) Meal for Fish Meal in Practical Diets for the White Shrimp Litopenaeus vannamei. Effects on Growth and in Vivo Digestibility. Aquacult 414-422.

18. Lee KJ, Powell MS, Barrows FT, Smiley S, Bechtel P, et al. (2010) Evaluation of Supplemental Fish Bone Meal Made From Alaska Seafood Processing Byproducts and Dicalcium Phosphate in Plant Protein Based Diets for Rainbow Trout (Oncorhynchus mykiss). Aquacult 302: 248-255.

19. Toppe J, Aksnes A, Hope B, Albrektsen S (2006) Inclusion of Fish Bone and Crab By-Products in Diets for Atlantic Cod, Gadus morhua. Aquacult 253: 636645 .

20. Foster I, Babbitt JK, Smiley S (2005) Comparison of The Nutritional Quality of Fish Meals Made From By-Products of The Alaska Fishing Industry in Diet for Pacific Threadfin (Polydactylus sexfilis). J World Aquacult Soc 36: 530-537.

21. Al-Ani M, Opara LU, Al-Bahri D, Al-Rahbi N (2007) Spectrophotometric Quantification of Ascorbic Acid Contents of Fruit and Vegetables Using the 2,4-Dinitrophenylhydrazine Method, J Food, Agricult Environ 5: 165-168.

22. Bai SC, Daniel KJ, Jang HK (1996) Development and Experimental Model for Vitamin C Requirement Study in Korean Rockfish, Sebastes schlegeli. J Aquacult 9: 169-178.

23. AOAC (2002) Official Methods of Analysis, (16thedn). Association of Official Analytical Chemists, Arlington.

24. Hwang JH, Lee SW, Rha SJ, Jeong DH, Han KH, et al. (2010) Nutritional
Characteristics of Eels (Auguilla Japonica) Fed a Diet of Yuza (Citrus junos Sieb Ex Tanaka). Kor J Fish Aquat Sci 43: 573-580.

25. Cho JK, Jin YG, Rha SJ, Kim SJ, Hwang JH (2014) Biochemical Characteristics of Four Marine Fish Skins in Korea. Food Chem 159: 200-207.

26. Nandeesha MC, Silva SS De, Murthy DS (1995) Use of Mixed Feeding Schedules in Fish Culture: Performance of Common Carp, Cyprinus carpio L, on Plant and Animal Protein Based Diets. Aquacult Res 26: 161-166.

27. Zeitler MH, Kirchgessner M, Schwarz FJ (1984) Effects of Different Protein and Energy Supplies on Carcass Composition of Carp (Cyprinus carpio L.). Aquacult 36: 37-48.

28. Lee SM, Lee JY, Kang YJ, Hur SB (1993) Effects of Dietary N-3 Highly Unsaturated Fatty Acid on Growth and Biochemical Changes in The Korean Rockfish Sebastes schlegeli. I. Growth and Body Composition. J Aquacult 6 : 89-105.

29. Kalogeropoulos N, Alexis MN, Henderson JJ (1992) Effect of Dietary Soybean and Cod-Liver Oil Levels on Growth on Growth and Body Composition of Gilthead Bream (Sparus aurata). Aquacult 104: 293-308.

30. Saglio PH, Fauconneau B, Blanc JM (1990) Orientation of Carp Cyprinm carpio $\mathrm{L}$ to Free Amino Acids from Tubifex Extract in an Olfactometer. J Fish Biol 37: 887-898.

31. Ronnestad I, Fyhn HJ (1993) Metabolic Aspects of Free Amino Acids in Developing Marine Fish Eggs and Larvae. Rev Fish Sci 1: 239-259.

32. Sivaloganathan B, Walford J, Ip YK, Lam TJ (1998) Free Amino Acids and Energy Methabolism in Eggs and Larvae of Seabass Lstes calcarifer. Mar Bio 131: 695-702.

33. Park YH, Jang DS, Kim SB (1997) Processing of the Sea Food. Hyungsul Press, Seoul, Korea 166-168. 